НАУКОВЙ̆ ВІСтинан

Scientific messenger of Lviv National University

(2010)

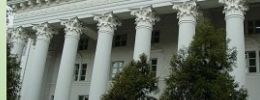

1.

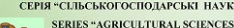

Том 22 № 93 2020
Науковий вісник Дьвівського національного університету ветеринарної медицини та біотехнологій імені С.3. Гжицького. Серія: Сільськогосподарські науки

Scientific Messenger of Lviv National University of Veterinary Medicine and Biotechnologies. Series: Agricultural sciences

UDC 338.48

\title{
Prerequisites and features of rural green tourism development in Lviv region
}

\author{
R. P. Paranyak, O. P. Rudenko, A. M. Marokyshka, V. V. Petruniv \\ Stepan Gzhytskyi National University of Veterinary Medicine and Biotechnologies Lviv, Ukraine
}

Article info

Received 26.08.2020

Received in revised form 28.09 .2020

Accepted 29.09.2020

Stepan Gzhytskyi National University of Veterinary Medicine and Biotechnologies Lviv, Pekarska Str., 50, Lviv, 79010, Ukraine.

Tel.: +38-096-813-07-93 E-mail: OlgaRudenko86@ukr.net
Paranyak, R. P., Rudenko, O. P., Marokyshka, A. M. \& Petruniv, V. V. (2020). Prerequisites and features of rural green tourism development in Lviv region. Scientific Messenger of Lviv National University of Veterinary Medicine and Biotechnologies. Series: Agricultural sciences, 22(93), 79_ 83. doi: $10.32718 /$ nvlvet-a9314

Ukraine is a country that occupies one of the most advantageous locations in Europe. The development of tourism in Ukraine will lead to an increase in tourist interest in Ukraine, to accelerate economic growth, support employment, structural modernization of the economy, filling the budgets of all levels. The strategic goal of tourism in our country is to create a competitive tourism product that can worthily occupy its niche in the world market. In the field of tourism in Ukraine, a new term "rural green tourism" has appeared, the development of which is progressing every year. Lviv region is one of those regions that has all the potential for the development of rural green tourism. The article presents the results of the analysis of green tourism in Ukraine and in the western region, strategic directions of development of the tourist sphere of Lviv region. The paper uses general and special methods for research and organization of green tourism: monographic, historical, abstraction and generalization, analysis, synthesis and comparison, system-structural analysis, problem-based approach, the study of statistics. The tourist resources of Lviv region that are used effectively are analyzed. The main directions of development of the tourism industry of Lviv region are identified, which has a significant potential, the rational use of which necessitates the attraction of innovative developments and investments. The development of tourism in the region requires a combination of numerous factors, namely: the availability of places of interest, the possibility of transport and infrastructure, safety of tourists and protection of their rights and more.

Key words: tourism, economic growth, tourism, rural green tourism, tourism, protected areas, socioeconomic problems.

\section{Передумови та особливості розвитку сільського зеленого туризму Львівщини}

\author{
Р. П. Параняк, О. П. Руденко, А. М. Марокишка, В. В. Петрунів
}

Львівський національний університет ветеринарної медицини та біотехнологій імені С. 3. Гжицького, м. Львів, Україна

Україна - ие краӥна, яка займає одне з найвигідніших розташувань у Європі. Розвиток сфери туризму в Украӥні призведе до збільшення туристичного інтересу до Украӥни, до прискорення економічного зростання, підтримки зайнятості, структурної модернізаиії економіки, наповнення бюджетів усіх рівнів. Стратегічною метою туризму в нашій державі є створення конкурентоспроможного туристичного продукту, що зможе гідно зайняти свою нішу на світовому ринку. У сфері туризму України з'явився новий термін “сільський зелений туризм", розвиток якого прогресує з кожним роком. Львівська область - одна з тих областей, яка має всі потенційні можливості для розвитку сільського зеленого туризму. У статті наведено результати аналізу зеленого туризму в Україні та в західному регіоні, стратегічні напрямами розвитку туристичної сфери Львівщини. У роботі використано загальнонаукові та спеціальні методи щңодо дослідження й організаџї зеленого туризму: монографічний, історичний, абстракції та узагальнення, аналізу, синтезу та порівняння, системно-структурного аналізу, проблемно-иільового підходу, вивчення статистичних даних. Проаналізовано туристичні ресурси Львівської області, що ефективно використовуються. Визначено головні напрями розвитку туристичної галузі Львівщини, що має значний потенціал, раціональне використання якого зумовлює необхідність залучати інноваційні розробки та інвестиції. Для розвитку туризму в регіоні необхідним є поєднання численних факторів, а саме: 
наявність місиь інтересу, можливість транспортного сполучення та інфраструктурне забезпечення, безпека туристів та захист їхіх прав тощуо.

Ключові слова: туризм, економічне зростання, туристична сфера, сільський зелений туризм, туристична діяльність, заповідні території, сочіально-економічних проблеми.

\section{Вступ}

Для багатьох країн світу туристична індустрія є найбільш прибутковою, такою, що динамічно розвивається та є основним джерелом доходів до бюджету. Туріндустрія входить в ТОП-5 галузей, що приносять найбільші доходи у світі. За даними прогнозів Всесвітньої туристичної організації, туристична сфера вже в найближче десятиліття вийде на перше місце в обсязі світового експорту. Туризм стимулює розвиток майже всіх галузей економіки, а саме: промисловості, торгівлі, будівництва, транспорту, сільського господарства, побутового обслуговування, малого і середнього бізнесу, виступаючи каталізатором соціальноекономічного розвитку країни. Саме тому питання проблем та перспектив розвитку туризму в Україні стоїть особливо актуально (Hnatyshyn et al., 2016; Riabova, 2018).

Україна - це країна, яка займає одне з найвигідніших розташувань у Європі. Розвиток сфери туризму в Україні призведе до збільшення туристичного інтересу до держави, прискорення економічного зростання, підтримки зайнятості, структурної модернізації економіки, наповнення бюджетів усіх рівнів (Bartoshchuk, 2012).

Стратегічною метою туризму в нашій державі має бути створення конкурентоспроможного туристичного продукту, що зможе гідно зайняти свою нішу на світовому ринку. Це не випадково, адже зараз туризм $\epsilon$ невід'ємною складовою частиною національного і світового ринку (Hnatyshyn et al., 2016).

Якщо можна зрозуміти, чому Україна поступається за туристичною привабливістю Греції (численні пам'ятки античної доби + середземноморський клімат) чи Туреччині (вдале розташування, дешевий сервіс, чудові кліматичні умови), то порівняно з Канадою, Польщею чи Нідерландами наша держава в сенсі туристичної привабливості суттєво програє передусім завдяки нерозкритому іміджу, провальній інфраструктурі та загалом малорозвиненій туристичній галузі. У нашій країні $\epsilon$ все необхідне для розвитку цієї сфери послуг. При цьому в Україні є передумови для розвитку різних форм туризму: зеленого, сільського, екологічного та комбінованих типів (Gerasimenko, 1997).

У даній сфері України 3'явився новий термін “сільський зелений туризм”, розвиток якого прогресує 3 кожним роком. Останнім часом мальовниче українське село стає привабливим місцем для туристів, які бажають відпочивати на лоні природи в етнографічних садибах, де можна поласувати національними стравами, познайомитися 3 традиціями та звичаями, 3 пам'ятками природи та архітектури тощо (Hlovatska, 2006).

Львівська область - одна $з$ тих областей, яка має всі потенційні можливості для розвитку сільського зеленого туризму. В окремих районах вже розвивається цей вид туризму, можливості його розвитку $є$ значними та вагомими. Проте сьогодні зелений туризм перебуває все-таки на напівлегальному становищі: немає достатньої законодавчої і нормативної бази, не визначений статус таких господарств і багато чого іншого (Zikeieva, 2013).

Meта даної роботи - уточнення поняття зеленого туризму та вивчення перспектив його розвитку в умовах Львівщини.

Для досягнення мети були поставлені такі завдання: сутність, стан та тренди туристичної діяльності; основні види та перспективи розвитку окремих видів туризму; особливості й умови розвитку туризму в Україні та Львівській області.

\section{Матеріал і методи досліджень}

Використано загальнонаукові та спеціальні методи щодо дослідження й організації зеленого туризму: монографічний, історичний, абстракції та узагальнення, аналізу, синтезу та порівняння, системно-структурного аналізу, проблемно-цільового підходу, вивчення статистичних даних

\section{Результати та їх обговорення}

Сільський зелений туризм для України є новим напрямом у туристичній галузі (Lytvyn \& Nek, 2013). Науковці працюють над питанням правильного тлумачення терміну “сільський зелений туризм” і визначення його місця у даній галузі.

У науковій літературі досить часто вживаються поняття "сільський туризм”, “зелений туризм”, “агротуризм”, “екотуризм”. Саме поняття сільського зеленого туризму було введене Спілкою розвитку сільського зеленого туризму в Україні, суть якого полягала не лише у відпочинку в сільській місцевості, а й у збережені та відновленні природи. Крім того, сільський зелений туризм $є$ важливим екологічним та етичним фактором, оскільки сприяє як фізичному, так i моральному оздоровленню населення. Туристичні потоки $є$ фактором взаємопроникнення культур, а також можуть допомогти зберегти чимало культур, ремесел та способів життя, що перебувають під загрозою зникнення сьогодні.

Враховуючи іноземний досвід розвитку сільського зеленого туризму, в Україні необхідно провести вивчення і наукове обгрунтування як сучасного етапу, так і перспектив розвитку цього виду туризму. На цій основі виявити території першочергового розвитку сільського зеленого туризму та розробити відповідні рекомендації як для органів місцевого самоврядування, так і громадян, які виявляють зацікавленість у цій діяльності. 
Позитивний вплив сільського зеленого туризму на вирішення соціально-економічних проблем села полягає передусім у тому, що він розширює сферу зайнятості сільського населення і дасть селянам додатковий заробіток.

Даний вид туризму в Україні розширює можливості зайнятості сільського господаря не тільки у виробничій сфері, а й у сфері обслуговування. При певному нагромадженні числа відпочиваючих з'являється потреба в задоволенні різноманітних запитів, а це своєю чергою стимулює розвиток сфери послуг: транспортних, відпочинково-розважальних, служби побуту, зв'язку, торгівлі та ін. (Lytvyn \& Nek, 2013).

Розвиток сільського зеленого туризму спонукає до поліпшення благоустрою селищ, тобто сільських садиб, вулиць, а також стимулює розвиток соціальної інфраструктури.

Особливо сприятливі умови для розвитку сільського зеленого туризму створюються на територіях національних і ландшафтних парків, де існує можливість поєднати відпочинок з пізнанням природного та історико-культурного потенціалу регіону. На даний час в Україні налічують понад п’ять десятків національних природних парків, із яких найстаріші - Карпатський та Шацький (1980 та 1983 року створення), найновіші ж - 2019 року створення (Бойківщина, Кам'янська Січ, Кремінські ліси, Нобельський).

Незважаючи на недостатне врегулювання такого виду туризму на законодавчому рівні, в Україні діяли і продовжують діяти такі програми розвитку туризму:

1) Програма розвитку туризму та рекреації у Львівській області на 2011-2013 рр.;

2) Сільський зелений туризм на Львівщині (соціальний бізнес-проект “Старий млин”);

3) “Віа Регія - Україна - культурний шлях Ради Свропи” (Lytvyn \& Nek, 2013).

Вкрай негативно на туристичному іміджі країни загалом позначилася війна на Донбасі, а також анексія найбільшого провідного туристичного регіону країни - Криму. Також, на відміну від сусідніх європейських країн, в Україні не набули належного поширення маркетингові стратегії розвитку туристичних підприємств. Про це свідчить відсутність або недостатня кількість належної реклами, промоцій загальнонаціональних іміджевих і туристичних брендів.

Ініціатором програм розвитку туризму та рекреації в нашій країні є Управління розвитку туризму та курортів України.
На даний момент в Україні існує система категоризації "Українська гостинна садиба", що надасть можливість забезпечити якісними послугами вітчизняних та закордонних туристів (Matviichuk \& Tyshchuk, 2014). До категорії мережі "Українська гостинна садиба" належать: базова категорія - садиба відповідає мінімальним вимогам, які встановлені до місць розміщення туристів та відпочиваючих; перма категорія - садиба відповідає встановленим мінімальним вимогам та вимогам, що стосуються озеленення території, паркування автотранспорту, мінімальних розмірів ліжок, площ санітарних приміщень; друга категорія - садиба відповідає встановленим вимогам першої категорії, наявність окремого входу для гостей, дитячого майданчика, лазні-сауни та доступу до загальної мережі інтернету; третя (найвища) категорія - садиба відповідає вимогам другої категорії та вимогам, які передбачають наявність басейну, гаража, в кожній кімнаті - телевізора, холодильника, оздоблення місць відпочинку натуральними матеріалами, цілодобового гарячого та холодного водопостачання.

Львівська область - одна 3 тих областей, яка має усі потенційні можливості для розвитку сільського зеленого туризму.

Для аналізу особливостей розвитку зеленого туризму у нашому регіоні звернемось до наукової літератури. Так, у роботі (Lytvyn \& Nek, 2013) розкрито сутність та основні види сільського зеленого туризму, досліджено історію появи послуг зеленого туризму, розкрито інформацію щодо популярності зеленого туризму в окремих регіонах України та за кордоном; на прикладі туристичних організацій Львівської області розглянуті основні проблеми розвитку сільського зеленого туризму, що згруповані у три блоки, та запропоновано використовувати кластерну модель надання послуг сільського зеленого туризму як один із дієвих способів вирішення існуючих проблем та сприяння розвитку сільських територій.

Про стан розвитку сільського зеленого туризму (C3T) в нашій країні загалом та у Львівській області зокрема ми можемо робити висновки за результатами огляду статистичних даних щодо кількості сільських і гостьових осель, залучених до надання нових туристичних послуг (табл. 1). Як бачимо, дані із різних джерел кардинально різняться.

\section{Таблиця 1}

Показники розвитку СЗТ в Україні за даними українських інформаційних сайтів станом на 17.02.2018 р.

\begin{tabular}{|c|c|c|c|c|}
\hline \multirow[b]{2}{*}{ Показники } & \multicolumn{4}{|c|}{ Джерела інформації } \\
\hline & $\begin{array}{c}\text { Сільський зелений } \\
\text { туризм }\end{array}$ & Зелений туризм & Карпати-info & Навколо світу \\
\hline $\begin{array}{l}\text { Кількість сільських і гостьових осель, що } \\
\text { залучені до СЗТ в Україні }\end{array}$ & 104 & 130 & 1058 & 245 \\
\hline $\begin{array}{l}\text { Кількість сільських і гостьових осель у } \\
\text { Львівській обл., що пропонують послуги СЗТ }\end{array}$ & 25 & 4 & 320 & 45 \\
\hline $\begin{array}{l}\text { Питома вага садиб Львівської обл., що } \\
\text { пропонують послуги СЗТ до загальної } \\
\text { кількості аналогічних садиб в Україні, \% }\end{array}$ & 4,35 & 9 & 35,26 & 15,34 \\
\hline
\end{tabular}


3 таблиці видно, що Львівська область, маючи значний рекреаційний потенціал, потужні можливості розвитку СЗТ, недостатньо використовує свої ресурси в цьому виді підприємництва. Питома вага гостьових осель, що надають “зелені” туристичні послуги нашого регіону, порівняно з кількістю таких осель в Україні $є$ ще досить незначною. Дані стосовно кількості осель на різних сайтах значно різняться, головна проблема в тому, що немає чітко визначених меж, які садиби вважати зеленими.

Окрім того, категоризація зараз не проводиться, оскільки не є обов'язковою законодавчо. Відсутність єдиної уніфікованої системи, яка б містила дані про усі агрооселі з різних регіонів України, є ще однією проблемою, що гальмує розвиток сільського зеленого туризму.

У Львівській області розвиток зеленого туризму тісно пов'язаний із реалізацією пріоритетних напрямів розвитку регіону (Savitska \& Savitska, 2013).

До інституційного блоку проблем розвитку сільського зеленого туризму регіону можна зарахувати відсутність законодавчої бази, необхідної для чіткого регулювання діяльності, єдиних інститутів, які б займалися аналізуванням і прогнозуванням розвитку сільського зеленого туризму.

Практична відсутність фінансової підтримки з боку держави, високі ставки за кредитами, відсутність пільг чи спрощеного оподаткування для суб'єктів СЗТ належать до фінансового блоку проблем розвитку C3T.

Для того, щоб отримати якісний продукт, слід спершу вкласти чимало зусиль у формування традиції і звичаїв щодо господарств, відомих як агрооселя, котра виступає передумовою й основою туристичного продукту сільського туризму. На ii базі формується пакет сукупних послуг клієнту: туристично приваблива місцевість, традиції та звичаї сільської гостинності у даній місцевості, історико-культурна спадщина, гастрономічне розмаїття тощо. Українське село здатне запропонувати туристові надзвичайно розмаїтий сільський туристичний продукт:

- самобутній побут,

- величезну історико-архітектурну народну спадщину,

- екологічно чисті продукти харчування,

- мальовничі ландшафти тощо.

Стратегічними напрямами розвитку туристичної сфери Львівщини є:

- розвиток сентиментального туризму для українців, євреїв, поляків тощо;

- організація національних і міжнародних наукових, культурних та ділових заходів (фестивалів, артистичних семінарів, конгресів, виставок тощо);

- розвиток асоціацій агро- і гірського туризму, сприяння розвитку туристичних послуг у сільській та гірській місцевостях;

- стимулювання промоційних компаній різноманітного рекреаційного та туристичного потенціалу області (лікувальні курорти, курорти з мінеральними водами, зимові види спорту тощо);

створення регіональної системи розповсюдження туристичної інформації та системи броню- вання через Інтернет, а також обласної мережі туристичних інформаційних центрів.

Перспективи подальшого розвитку у регіоні зеленого туризму пов'язані із:

- підвищенням ролі та популярності серед населення об'єктів природно-заповідного фонду (як от НПП “Сколівські Бескиди”, “Яворівський”, а також нещодавно створених "Бойківщина".та "Північне Поділля");

- започаткування практики відпочинку на базі садиб у зоні БР “Розточчя" (за винятком території природного ядра);

- створення сприятливого правового й економічного середовища для розвитку сільського туризму;

- створення ефективної системи забезпечення якості послуг, яка базується на потребах споживача, гарантує базові стандарти, включає критерії захисту навколишнього природного середовища тощо;

- формування стимулюючих та заохочувальних механізмів на усіх рівнях від рівня громад - до державного рівня;

- економічна підтримка розвитку сільського туризму шляхом залучення інвестицій, пільгового кредитування власників садиб для модернізації осель, підвищення кваліфікації, рекламування діяльності тощо;

- пошук додаткових можливостей для підвищення знань сільського населення і поширення інформації щодо відпочинку в українському селі та про історичні, природні, етнографічні особливості регіону.

Аналіз зеленого туризму в регіонах України довів, що значного розвитку такий вид туризму набуває в Західному регіоні (Matviichuk \& Tyshchuk, 2014). Перебування у селі дозволяє жителям міст долучитися до місцевої екзотики, етнографічних особливостей, оздоровитися цілющими водами і свіжим гірським повітрям, натуральною, екологічно чистою селянською їжею. До того ж у багатьох селах є цінні пам'ятки дерев'яної архітектури - старовинні церкви, а також пам'ятники природи та історії. Можна ознайомитися 3 осередками народних промислів - лозоплетінням, гончарством, вишиванням, ткацтвом, різьбленням по дереву. Це створює сільським господарям та іншим ентузіастам організації відпочинку на селі широкі можливості з розробки і реалізації цікавих програм для гостей сільських садиб

\section{Висновки}

Як свідчить аналіз, туристичні ресурси Львівської області використовують ефективно, однак не повною мірою. Туристична галузь Львівщини має значний потенціал, раціональне використання якого зумовлює необхідність залучати інноваційні розробки та інвестиції, що в кінцевому підсумку сприятиме формуванню конкурентоспроможності регіону (Pavlenchyk, 2019).

Для розвитку туризму в регіоні необхідним є поєднання численних факторів, як от: наявність місць інтересу, можливість транспортного сполучення та інфраструктурне забезпечення, безпека туристів та захист їхніх прав тощо. 
Ще одне важливе питання, яке слід розв'язати інформаційне забезпечення зеленого туризму, створення інформаційних центрів для туристів, як у всьому світі. А це - досить непроста і дорога справа.

За бажання та старання практично всі райони й населені пункти Львівщини знайдуть чим привабити туристів. Але над цим потрібно працювати.

\section{References}

Bartoshchuk, O. V. (2012). Otsinka rozvytku turyzmu v Ukraini. Investytsii: praktyka ta dosvid, 7, 82-86. URL: http://www.investplan.com.ua/?op=1\&z=1901\&i=20 (in Ukrainian).

Gerasimenko, V. G. (1997). Osnovy turistskogo biznesa. Odessa: Chernomor'e (in Russian).

Hlovatska, V. V. (2006). Silskyi zelenyi turyzm: sutnist, funktsii, osnovniorhanizatsii: [Pro rozvytok zelenoho turyzmu (SZT) v Ukraini]. Ekonomika APK, 10, 148155 (in Ukrainian).

Hnatyshyn, M. S. Hrynchuk, N. V., \& Teliuk, K. F. (2016). Rozvytok turystychnoi haluzi Lvivskoi oblasti yak skladovoi chastyny turystychnoi sfery Ukrainy. Naukovyi visnyk NLTU Ukrainy, 26(6), 175-184. doi: 10.15421/10.15421/40260627 (in Ukrainian).

Lytvyn, I. V., \& Nek, M. O. (2013). Problemy ta perspektyvy rozvytku silskoho zelenoho turyzmu v rehioni. Rehionalna ekonomika, 2, 81-88. URL: http://dspace.nbuv.gov.ua/handle/123456789/68180 (in Ukrainian).

Matviichuk, L. Iu., \& Tyshchuk, I. V. (2014). Rehionalni osoblyvosti poshyrennia zelenoho turyzmu v Ukraini. Zbirnyk naukovykh prats. Lutskyi natsionalnyi tekhnichnyi universytet. Lutsk: RVV Lutskoho NTU, 11(43), 149-157 (in Ukrainian).

Pavlenchyk, N. (2019). Efektyvnist vykorystannia turystychnykh resursiv Lvova. Ekonomiko-sotsialni vidnosyny $\mathrm{v}$ haluzi fizychnoi kultury ta sfery obsluhovuvannia: materialy II Mizhnar. nauk.-prakt. konf. Lviv, 104-107 (in Ukrainian).

Riabova, T. A. (2018). Stan ta perspektyvy rozvytku turystychnoi haluzi v Ukraini. Efektyvna ekonomika, 4, 1-4. URL: http://www.economy.nayka.com.ua/pdf/ 4_2018/51.pdf (in Ukrainian).

Savitska, O. P., \& Savitska, N. V. (2013). Stratehiia rozvytku turystychnoi industrii $\mathrm{v}$ Ukraini: rehionalni aspekty. Visnyk Natsionalnoho universytetu "Lvivska politekhnika". Problemy ekonomiky ta upravlinnia, 754, 68-74. URL: http://nbuv.gov.ua/UJRN/ VNULPP_2013_754_12 (in Ukrainian).

Zikeieva, S. H. (2013). Turystychna haluz Ukrainy v period yevrointehratsii: sotsialno-ekonomichnyi aspekt. Ekonomika i menedzhmen tkultury, 1, 74-82. URL: http://nbuv.gov.ua/UJRN/ekmk_2013_1_13 (in Ukrainian). 